Lektorált tanulmányok

\title{
Múzeumi látogatói élmény
}

\author{
Szerző: Bodnár Dorottya ${ }^{1}$
}

Jelen cikk részletes szakirodalmi áttekintést nyújt az új muzeológia paradigmájához vezetô trendekrôl, a múzeumi látogatói élményrôl, valamint az interpretációt segítô módszerekrôl. A szerző az interpretációt segító módszereket beilleszti PINE és GILMORE (1998) élménymodelljének múzeumi kontextusban továbbfejlesztett verziójába. Az eszképizmus dimenziójának részletes vizsgálata ugyancsak megtörténik annak változatos értelmezései alapján, valamint az edutainment gyakorlata is beillesztésre kerül a modellbe. A cikk előkészítésül szolgál a témában megvalósítandó primer kutatáshoz.

Kulcsszavak: új muzeológia, múzeum, látogatói élmény, eszképizmus, PINE és GILMORE.

\section{Bevezetés}

Jelen cikk a múzeumi látogatói élmény területére fókuszálva annak egy szeletét kívánja részletesen megvizsgálni. A központi témához több oldalról közelít, áttekintve az új muzeológia, valamint a látogatói élmény szakirodalmát. A szerzô elsősorban a kiállítások által nyújtott élményre fókuszál, amelyre bizonyítottan hatással vannak olyan, az interpretációt segítő módszerek, mint például az interaktivitás, a több érzékszervre ható eszközök vagy a közös alkotás. A szerző egy általa kiválasztott élménymodellt állít elemzése középpontjába, amelyet múzeumok esetén kíván alkalmazni és továbbfejleszteni. B. JOSEPH PINE II és JAMES H. GILMORE 1998as négydimenziós élménymodellje publikálásának 20. évfordulóján még mindig népszerúnek tekinthető, hisz számos esetben alkalmazzák a turisztikai kutatásokban. A cikk a fenti modell egyik dimenzióját, az eszképizmust elemzi részletesen, amelyet erősen befolyásolnak az új muzeológia kapcsán bemutatott, interpretációt segítô módszerek.

\section{2. Új muzeológia}

A XX. század utolsó évtizedeiben a múzeumok megváltozott környezeti feltételekkel szembesültek, napjaink látogatóinak igényei különböznek az előző nemzedékeknél tapasztaltaktól. A múzeumi szakma olyan elvárásokat és trendeket érzékelt, amelyek sok esetben eltértek a feladataikról, funkciójukról, múködési formájukról alkotott képtől. A múködésükkel kapcsolatos nehézségek tovább hangsúlyozták a változás szükségességét. A fenti folyamatok felismerése, a hozzájuk való alkalmazkodás hosszú idó alatt zajlott le, sőt az intézmények jelentős részében még napjainkban is folyamatban van. Az 1. ábra a régitôl az új muzeológiáig vezető utat ábrázolja, amelynek az egyes állomásai a legfontosabb változásokat jelzik.

A '70-es években Nagy-Britanniában a múzeumokat a nemzeti hanyatlás szimbólumainak tekintették (HEWISON 1987). A múzeumokat elavult, elitista és a modern világtól elzárt intézményeknek vélték, amikre felesleges közpénzt költeni (HUDSON 1977), és amelyek „kulturális hatóságokként" múködtek (HARRISON 1993).

A múzeumok a látogatók igényeivel egybecsengó fókuszpont váltásra kényszerültek, a je-

\section{Út a koraitól az új muzeológiáig}

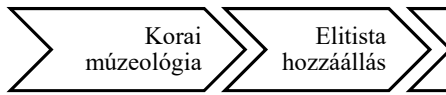


lenkori társadalom elvárásainak megfelelően a hangsúlyt a tárgyakról az emberekre helyezték át (SIMPSON 1996, HUDSON 1998). A kiállított tárgyak jelentéstartalommal való felruházása (meaning-making) a modern múzeumok kulcstevékenysége. A jelenkori társadalom tagjai aktív szerepet töltenek be a múzeumok életében (SIMPSON 1996), ahol vitára ösztönzik és bevonják őket az interpretációba. A professzionális, tudományos háttér nagymértékben hozzájárul az intézmények megbecsüléséhez.

A múzeumoknak érdemes számításba venni a szélesebb társadalmi csoportok megszólítását, hiszen így lehetőséget teremthetnek akár a társadalmi egyenlőtlenségekről és a diszkriminációról való párbeszédre is (SWARBROOKE 2000, SANDELL 2007), amely kiválthatja a látogatás során kulcsfontosságúnak számító érzelmi hatást.

A kutatók bebizonyították, hogy a szabadidő és a szórakozás ösztönöz leginkább a múzeumok meglátogatására (MOORE 1997, PACKERBALLANTYNE 2002), ezeket követi a másodlagos motivátorként aposztrofált tanulás. A múzeumok, amelyek közösségi térként is funkcionálnak (THYNE 2001), valamint a társadalmi jólét előmozdításában is fontos szerepük van (CHATTERJEE-NOBLE 2013), felelősek az objektumok és mútárgyak jelentésének látogatóbarát befogadását szolgáló környezet megteremtéséért. A szórakoztató funkció mellett sokan foglalnak állást, ugyanakkor néhány kutató kétségeket támasztva megfontolásra, az egyensúly megtartására ösztönöz (KOTLER-KOTLER 2000).

\section{A látogatói élmény meghatározása}

Az élménygazdaságtan fogalma olyan, a XX. század legvégén kialakult jelenséget takar, amelynek középpontjában az élmény keresése és az élmény biztosítása áll: a keresleti oldalon a fogyasztói magatartás meghatározó eleme a fogyasztói döntés révén megszerzett élmény, a kínálati oldalon pedig az egyetlen jelentős versenyelőny abból származik, hogy egy vállalat milyen intenzitású élményt képes terméke vagy szolgáltatása megvásárlójának és elfogyasztójának nyújtani (MICHALKÓ-RÁTZ 2005). Az élménygazdaságtan hatása minden szektorba begyúrúzött, a turizmus iparágát ugyanúgy érinti, mint a múzeumi szférát vagy a hétköznapi szolgáltatásokat.

A cikk keretében a szerző a látogatói élmény egy olyan definícióját kívánja alkalmazni, amelyet PACKER és BALLANTYNE (2016) egy 16 definíciót és 18 látogatói élménymodellt összegyưjtő és elemző munka eredményeként alakított ki. A vizsgálat alapján meghatározható, hogy az élmény egy, a látogatóban lezajló szubjektív dolog, amely az átélt eseményeken és a környezeten alapul. A szolgáltató nem egy mesterségesen megrendezett élményt nyújt, hanem a megfelelő környezet kialakításával csupán lehetőséget biztosít az élmény megélésére (WALLS et al. 2011, SCHMITT 1999), amelyből a látogató maga válogatja ki a számára legfontosabb elemeket. HENNES (2010) szerint a kiállítás nem maga az élmény, hanem csak az élmény platformja. A kutatók egy része egyetlen pillanatként tekint az élményre, mások egy folyamatként. DEWEY (1938/1963) folyamatosság elve alapján minden élmény megváltoztatja magát a személyt is, aki azt megéli, melynek következtében befolyással van a jövőbeli élményeire is. WEAVER (2007) ugyancsak a látogatói élmény holisztikus szemléletét támogatja a meghívás pillanatától (a potenciális látogatót elérố reklámtól és a parkolóban őt ért behatásoktól kezdve) a fináléig (benyomások, amelyeket magával visz). Így PACKER és BALLANTYNE (2016) azt hangsúlyozza, hogy minden esetben tisztázni kell, hogy az élmény a teljes folyamatra vonatkozik (tervezés, megvalósítás, emlékezés) vagy csak egy adott pillanatra, eseményre. Ugyanakkor értelmezésük szerint az élmény mindenképpen elhatárolható a mindennapi folyamatoktól, akár az érzelmi intenzitása miatt, akár az időbeli vagy térbeli egyedisége okán (nem egy földhözragadt vagy közhelyes esemény, mint ahogy azt WALLS és társai (2011) említik). PACKER és BALLANTYNE (2016) szerint természetesen nem minden múzeumi látogatás éri el egy kiemelkedő, belső átalakulást eredményezó élmény szintjét, viszont azáltal, hogy a látogató elmeséli a tapasztalatait, vagy megmutatja a fotókat, esetleg a közösségi médiában jelenik meg a helyszínnel, emlékezetes élménnyé válik számára az eset. McINTOSH és SIGGS (2005) azonban az általános fogyasztói élményeknél magasabb értékszintet tulajdonít a turisztikai élményeknek.

A fentiek alapján a szerző jelen munka során a látogatói élményt PACKER és BALLANTYNE (2016:133) definícióját a jelenség fontosságával kiegészítve értelmezi, mint „az egyén azonnali vagy folyamatban lévó, szubjektív és személyes válasza egy tevékenységre, környezetre vagy eseményre, amely a megszokott környezetén kívül zajlik" és amely a látogató számára különös jelentőséggel bír.

A látogatói élmény meghatározását a 2. ábrán látható koncepcionális vázlat szemlélteti. 
A látogatói élményhez kapcsolható kulcstényezốk koncepcionális vázlata

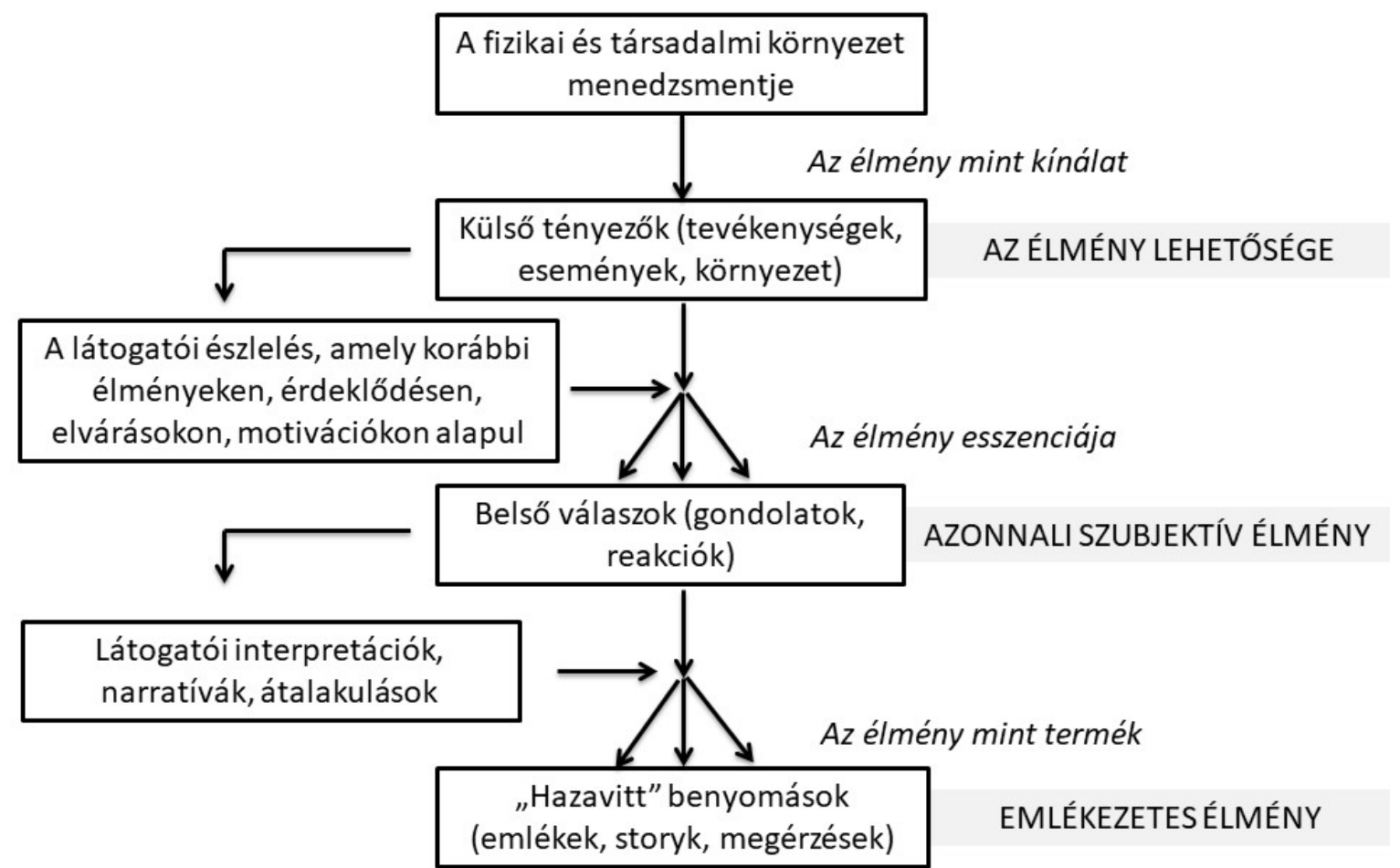

MASBERG és SILVERMAN (1996) szerint a múzeumi látogatói élmény egy nagyon komplex és többdimenziós fogalom, amely az önmagában vett tanulásnál szélesebb jelentéstartalommal bír. Ez egybevág a ROUNDS (1999) által meghatározott, a muzeológiában megfigyelhető változással: a múzeumok kultúra-átadási paradigmája felől elmozdulás történt a látogató általi jelentéstartalommal való megtöltés (meaning-making) paradigmája felé. Ez utóbbi elmélet támogatói szerint ahelyett, hogy egy adott kiállítás által kínált egyszerú tartalmat fogadnák be, az emberek a múzeumi látogatást arra használják, hogy a személyes belső céljaikat elérjék, számos emberi igényük némelyikét kielégítsék és az önismeretüket javítsák (ROUNDS 1999, SILVERMAN 1995). SILVERMAN (1995) azt is állítja, hogy egy történeti múzeumban a szinte kizárólag történelmi fókuszú oktatási célkitúzés valójában hátráltatja az egyéb lehetséges hozzáadott értékek elérését, amelyeket a múzeumok a látogatói igényeknek való megfelelés érdekében tehetnének.

\section{Múzeumi interpretációt segító módszerek, mint a látogatói élményre ható tényezók}

Az alábbiakban bemutatásra kerülnek azok a múzeumi interpretációt segítő módszerek, amelyek támogatják a múzeumi funkciók és célkitűzések teljesítését. Ezek közé tartoznak például az interaktív eszközök, a kézzel fogható tárgyak, az információtechnológiai eszközök, illetve az interaktív edutainment módszerei.

A több érzékszervre ható élményelemek, valamint a közös alkotás (co-creation) lehetősége ugyancsak kiemelendő, ahogyan az autenticitás (hitelesség) különböző formáit erősítő eszközök is. A múzeumi interpretáció célja minden esetben az, hogy a megfelelő eszközök segítségével lefordítsák egy-egy kiállítás mondanivalóját a látogatók számára, így segítve azok megértését. 


\subsection{INTERAKTIVITÁS}

Az interaktív kifejezés jelentése, a latin inter (között) + activus (tevékeny) szavak összerakásából eredően: kölcsönös érintkezésen alapuló, a nézö/felhasználó/ látogató tevékeny részvételét kívánó. A cselekmény tehát két tényező, ember-ember, ember-eszköz, eszköz-eszköz, között történhet. Ugyanaz a cselekmény megismételhetô, de az arra adott válaszok alapján meg is változhat. Az interaktív eszközök célja nem feltétlenül a szórakozás, mint a később tárgyalt edutainment esetén, hanem a kipróbáláson keresztül elérhető jobb érthetőség, a szemléltetés, valamint a tanultak elmélyítése.

Az utóbbi évtizedekben a látogatók számos dinamikus eszközzel találkozhatnak a múzeumokban (például audio-video eszközökkel, megérinthetô tárgyakkal, interaktív térképekkel), amelyek kiegészítik vagy helyettesítik a hagyományos statikus eszközöket (maketteket, fotókat, leírásokat). BRADBURNE (2002) hangsúlyozza azonban, hogy az interaktivitás önmagában nem elég, a hands-on, minds-on és hearts-on jellemzók, tehát a kézzel foghatóság, a szellemileg lebilincselő témák, valamint az érzelmekre való hatás egyaránt fontosak egy kiállítás esetén.

Az ausztráliai Powerhouse Museumban és a Scitech Discovery Centre-ben készült kutatásra alapozva FALK és társai (2004) a látogatók azon tapasztalatát közvetítik, hogy az interaktív élmények a hatékony tanuláshoz vezetnek, tekintettel arra, hogy:

- beszélgetésre, kommunikációra, és közös alkotásra ösztönöznek,

- személyes visszajelzést biztosítanak,

- elősegítik a megtapasztalás által elérhetô tanulást (learning by doing).

A szerzők arra is rámutatnak, hogy amennyiben a látogatók egy múzeumban találkoznak interaktív eszközökkel, úgy mind rövid, mind hosszú távon szignifikánsan megváltozhat ezen intézményekhez való kezdeti hozzáállásuk („öreg” és „poros”).

\subsection{BEVONÓDÁS}

Egy szabadidős tevékenységbe való bevonódás azt az állapotot, valamint az egyén észleléseit jelöli, amely az adott tevékenységhez való szoros kapcsolódás, elköteleződés esetén alakul ki (BEATON et al. 2009). HOUSTON és ROTHSCHILD (1978) "tartós bevonódásnak" nevezi, amikor az egyén viszonylag hosszú időn keresztül egy különleges szituációra, tárgyra, dologra fordít figyelmet, foglalkozik azzal (HUANG et al. 2010). McINTYRE (1989) szerint ez az állapot egy hosszú belefeledke- zés egy tevékenységbe, amelynek különleges jelentősége van az egyén számára.

FORGAS-COLL és szerzőtársai (2017) elsőként tesztelték múzeumi kontextusban a bevonódás és a látogatók jövőbeli szándékának kapcsolatát. A kutatást a barcelonai Picasso Múzeumban és a Míró Alapítványnál végezték el összesen 1091 látogató bevonásával. A szerzók arra a következtetésre jutottak, hogy minél magasabb a múvészetbe való személyes bevonódása a látogatónak, annál magasabb az elégedettsége, és annál pozitívabbak a jövőbeli szándékai. HOU és társai (2005) szintén pozitív kapcsolatot tártak fel a tartós bevonódás és a desztináció vonzereje között a kulturális turisztikai desztinációk esetén. A bevonódás és az elégedettség között több kutató pozitív kapcsolatot mutatott ki, így például LU és társai (2015), KIM és társai (2015), valamint LEE és CHANG (2012).

\subsection{EDUTAINMENT, AVAGY SZÓRAKOZVA TANULÁS}

„A tanulás egy természetes és élethossziglan tartó folyamat, amelynek a legalapvetőbb eredménye a személyes tudatfejlődése" (HOOPER-GREENHILL 2007:45). A tanulás HOOPER-GREENHILL (1999) szerint akkor a legeredményesebb, ha élvezetes körülmények között történik. Ez a konstruktivista oktatási elméletet tükrözi, amely szerint az emberek a tapasztalataik alapján építik fel a saját tudásukat és értelmezésüket az óket körülvevő dolgokról (PIAGET 1995, BRUNER et al. 1976, VYGOTSKY 1978).

Az edutainment a szórakozás és tanulás keveréke, ami annak érdekében jön létre, hogy egy sikeres és ösztönzó környezetet biztosítson a tanulás számára (JEGERS-WIBERG 2003). Az ipari társadalomban a szabadidő a kemény munka jutalmaként volt meghatározva, és a pihenéssel volt egyenértékú. Ma azonban a szabadidejüket inkább az önfejlesztésre használják az emberek (WHITE et al. 2004).

WHITE és társai (2004) szerint a szórakozva tanulás lehet egy esemény vagy egy program, ahol a szórakozási jelleg az elsódleges szempont, az oktatási tartalom pedig valójában egy melléktermék. Nehéz a két véglet között egyensúlyt találni. Feltárva annak kockázatait, a szórakozva tanulás gyakorlatát számos kutató ellenzi. A múzeumokban gyakran előfordul, hogy a szórakozási szempont az oktatási cél rovására megy (GOODLAD-McIVOR 1998), és az is megtörténhet, hogy egy idő után az emberek nem lesznek hajlandóak tanulni anélkül, hogy valamilyen szórakozásban ne lenne részük közben (BLOOMHANYCH 2002). Emiatt rosszabb esetben a láto- 
Lektorált tanulmányok

gató a tanulásra nem célként fog tekinteni, hanem inkább mint egy akadályra, amely elválasztja őt a szórakozástól.

Ugyanakkor a tanulás konstruktivista elméletére alapozva a múzeumi szakma számos szakembere támogatja az interaktív eszközöket, mint a szórakozva tanulás egyik fontos elemét, hiszen ezek az eszközök nemcsak a tanulást segítik elő, hanem a közönséget is sokkal aktívabbá teszik a látogatások során (FALK et al. 2004). Azonban a konstruktivista tanulás elve nem tud megvalósul$\mathrm{ni}$, ha az átadott és befogadott ismereteket a fogyasztó nem gondolja át, nem építi be a tudatába (SALOMON 1983). ADDIS (2005) szerint a tanulás eredményessége nagyban múlik az egyénen, így például a múzeumi látogatón, akit az üzenet elér, hiszen ő dönti el, hogyan szívja magába az információt, és hogyan fogja azt használni. Így tehát a látogató válik felelőssé azért, hogy mit tanul egyegy látogatásból.

\subsection{KÖZÖS ALKOTÁS}

A gazdasági folyamatokat a szolgáltatásdomináns logika (service-dominant logic) jellemzi az utóbbi évtizedekben (VARGO-LUSCH 2004). Ennek központi gondolata a dialógus, a közös probléma és igényfeltárás, valamint a személyre szabott megoldások, élmények kialakítása.

A szolgáltatásdomináns logikához vezetó fókuszeltolódások nagyon hasonlítanak az új muzeológiát jellemző, korábban leírt folyamatokra, mint például az emberek/fogyasztók középpontba helyezése a tárgyak helyett, illetve a múzeum, mint az érték és az örökség meghatározására hivatott intézmény egyedülállósága helyett a látogatóval való közös értékmeghatározás (vállalat és fogyasztó kapcsolata). A közös alkotás (co-creation) a múzeumi kontextusban ugyancsak kiemelkedôen fontos módszer (PRENTICE 2001, COUNTS 2009), amellyel a látogatók bevonását, a közös értékteremtést lehet elósegíteni (THYNEA-HEDE 2016). GOULDING (2000) szerint az ideális múzeumi látogatói élmény megélésében a látogatók aktív partnerek (active agent), akik tudatosan vesznek részt a folyamatban. A közös alkotás a látogatói élmény szerves része (THYNEA-HEDE 2016) amely erôsen befolyásolja az észlelt élményérték és a fogyasztói elégedettség közötti kapcsolatot (PREBENSEN et al. 2015).

\subsection{AUTENTICITÁS}

THYNEA és HEDE (2016:1481) WANG (1999) munkájára való hivatkozással azt állítják, hogy „múzeumi környezetben az autenticitás, vagyis a hitelesség fogalma azt takarja, hogy egy tárgy vagy múalkotás azon kultúra vagy múvész hagyományainak, szokásainak megfelelóen keletkezett, amelyből/akitől azt származtatják". Ez fémjelzi a múzeumokat, és habár ezen intézményeket sokszor az általuk kiállított tárgyak alapján ítélik meg (TRILLING 1978), a múzeumok különbözó okoknál fogva mégsem az eredeti darabokat, hanem diorámákat, replikákat, szimulációkat, modelleket vagy akár más múvészek inspirációs alkotásait állítják ki egy adott mútárgyról (THYNEA-HEDE 2016).

Az új muzeológia azonban azt hangsúlyozza, hogy a múzeumi látogatói élményt nem csak a kiállított tárgyak határozzák meg, az emberek ma már sokkal aktívabbak és fizikailag is részt vesznek a látogatás folyamatában, semmint hogy csak megfigyelók legyenek (HUME 2015). Ennek megfelelóen egy múzeumot nem lehet kizárólag annak autentikus jellege alapján megítélni. WANG (1999) nem támogatja a hitelesség tárgyalapú szemléletét, inkább azt kibővítve, az észlelt hitelességre érdemes a fókuszt helyezni, amely egyes tevékenységekben való aktív részvétellel befolyásolható. LEIGH és társai (2006) az amerikai polgárháború eljátszásának kutatása alapján fontos szerepet tulajdonítanak a látogatói élménynek az észlelt autenticitás elérésében. BARON és társai (2001) a yorki Jorvik Viking Múzeumban végzett kutatásuk alapján állítják, hogy a látogatói élmény nem megfogható elemei, mint például a látvány, a hangok, a szagok váltják ki a legfontosabb érzelmi reakciókat, és ezek lesznek a látogatás legemlékezetesebb részei. Mindkét fenti kutatásban (LEIGH et al. 2006, BARON et al. 2001) fontos szerepet játszottak a látogatók érzékszervei és képzelőereje, melyek lehetôvé tették, hogy a látogatók a múzeummal karöltve vegyenek részt az élmény közös megteremtésében. COUNTS (2009) szerint az úgynevezett ikonikus autentikus (PEIRCE 1998) kiállítások esetében, ahol másolatok is szerepet kapnak, számos lehetőség van a látogató bevonására, például replika tárgyak kézbe adásával vagy interaktív tevékenységekkel, amelyek lehetőséget adnak a közös alkotásra. Számos múzeum alakított ki az elmúlt években úgynevezett demonstrációs tárgyakból álló gyújteményt, amely a kevésbé értékes és nem ritka mútárgyakat foglalja magába. Ezek a látogató által kézbe vehetôk, amely segíti az interpretációt, a megértést, ugyanakkor különleges élményt is nyújt. A látogatók aktív részvételének biztosítása és a múzeumi élmény fokozása érdekében az attrakció tervezése során fontos mind az eredeti, mind a replika tárgyak, kiállítási elemek, környezet alkalmazása és kialakítása. 


\subsection{INFOKOMMUNIKÁCIÓS TECHNOLÓGIÁK}

Az infokommunikációs technológiai (ICT) eszközök és digitális tartalmak, mint például multimédiás installációk, kiterjesztett valóságra épüló mobil applikációk és virtuális rekonstrukciók, az élményközpontú látogatói igények egy részének kielégítésére szolgálnak. Kézzelfogható attrakciókat egészíthetnek ki, de akár a láthatatlan, kézzel meg nem fogható attrakciókat is láthatóvá teszik (például egykori épületet virtuálisan bejárhatóvá tevó applikáció).

A múzeumok egyre több esetben alkalmazzák ezeket az eszközöket, tekintettel arra a tényre, hogy az ICT növeli a vonzerőt, javítja az érthetôséget, valamint a hozzáférhetőséget, akadálymentességet (HJALAGER 2010). A kérdés már nem az, hogy használják-e a múzeumi fejlesztések során ezeket az eszközöket, hanem hogy melyek lesznek a leghatékonyabbak a látogatói élményre nézve, amelyek mélyebb, gazdagabb megértést, és erősebb bevonódást eredményeznek (TOMIUC 2014).

A technológiai fejlődéssel lépést tartani nagyon költséges volna a köztudottan jellemzően szúkös pénzügyi kerettel rendelkezó múzeumok számára. Emiatt sok esetben csak idószaki kiállítások esetén próbálhatók ki technológiai újítások, azonban nagyon fontos, hogy az állandó kiállítás, amely az alapvetố vonzerôt jelenti, stabil, napjaink igényeinek megfelelő kínálattal rendelkezzen.

\subsection{MULTISZENZORÁLIS ÉLMÉNY - TÖBB ÉRZÉKSZERVRE HATÓ ÉLMÉNYEK}

A múzeumi látogatói élményre eróteljes - gyakran flow-szerú (CSÍKSZENTMIHÁLYI 1990) - hatást gyakorolnak a kiállítási tárgyakat kiegészítő megfogható eszközök, a hangok, a szagok, az interaktív elemek (például szerepjátékra ösztönző eszközök), valamint a dinamikus eszközök (HARVEY et al. 1998). A yorki Jorvik Viking Múzeumban (VI et al. 2017) a látogatóknak több érzékszervre ható élményben lehet részük, például megtapinthatnak viking kori tárgyakat, megkóstolhatják a hagyományos szárított halat, érezhetik a kihelyezett tárgyak illatát, sétálhatnak a viking központban éló emberek és állatok között, valamint meghallgathatják a viking mondákat.

A multiszenzorális kialakítás gazdagítja a kiállítást, és elősegíti a látogatói élmény emlékezetességét (EARDLEY et al. 2016, DOLCOS-CABEZA 2002), mivel a hétköznapi életben is folyamatosan ilyen jellegú behatások érik az embereket, illetve az ilyen hatásokkal rendelkezó események képesek jobban bevésődni az emberek emlékezetébe.
Számos kutatás valósult meg múzeumi környezetben a különböző érzékszervre ható eszközök alkalmazásával és ezek látogatói élményre való hatásával kapcsolatban (LAI 2015, CIOLFI-BANNON 2002, HARLEY et al. 2016).

\subsection{FIZIKAI, SZOCIÁLIS AKADÁLYMENTESÍTÉS}

A multiszenzorális elemekkel gazdagított kiállítás nem csupán az emlékezetes látogatói élmény egyik fontos feltétele, de azt is lehetóvé teszi, hogy bármilyen fogyatékkal élő látogató számára élvezhetô legyen a közeg. Az információk többszintú átadása több szempontból jelent pozitív hozadékot a látogatóknak. HOOPER-GREENHILL (1999) szerint a múzeumok és a galériák talán az egyedüli intézmények a társadalomban, amelyeknek lehetôségük van az eltéró tudásszinttel rendelkezó, tanulni vágyó közönség igényeinek kiszolgálására. Több célcsoport (korcsoport, érdeklődési szint, szúk időkeret) számára válik értelmezhetôvé egy-egy kiállítás, amennyiben az intézmények a könnyen értelmezhetőség (easy to read/easy to understand) elveit is figyelembe veszik.

\section{PINE és GILMORE (1998) négydimenziós látogatói élmeny modelljének elemzése}

A múzeumi élmények meghatározását és mérését számos kutató kísérli meg különböző modellek felállításával, majd empirikus kutatással vizsgálják az egyes keretrendszerek érvényességét. A látogatói élmény mérése menedzsment szempontból fontos feladat, hiszen az összefügg a látogatók jövőbeli viselkedési szándékával, mint például a visszatérési hajlandósággal vagy a szájreklámmal (RADDERHAN 2015, HUANG et al. 2012, DIRSEHAN 2012, HARRISON-SHAW 2004).

\subsection{A NÉGYDIMENZIÓS MODELL BEMUTATÁSA}

A szerző doktori kutatásának fókuszában az alábbiakban bemutatásra kerülő négydimenziós élménymodell (4E modell) és annak továbbfejlesztése áll. B. JOSEPH PINE II és JAMES H. GILMORE 1998-ban a Harvard Business Review-ban publikált Welcome to the experience economy ${ }^{2}$ címú tanulmánya rendkívül nagy hatással volt a fogyasztói élmény tudományterületének fejlődésére. Az úttörónek tekinthetô munka hatását a FERREIRA és TEIXEIRA (2013) által készített bibliometriai elemzés támasztja alá.

\footnotetext{
${ }^{2}$ Üdvözlünk az élménygazdaságban
} 
PINE és GILMORE modellje szerint az élményt két jellemző alapján lehet tipizálni, az egyik a részvétel jellege (aktív, passzív), a másik az eseményt, előadást az egyénnel összekötő kapcsolat jellege (elmerülés, felszívódás). A két jellemző mentén PINE és GILMORE egy négydimenziós modellt állítottak fel, amelynek minden szegmensében az élmény egy típusa - szórakozás, tanulás, esztétika, eszképizmus - jelenik meg, ahogyan azt a 3. ábra mutatja.

A két jellemző elvont elnevezése miatt gyakran nehezen értelmezhetôek a modell részei, ami az egyes élménytípusok elhelyezhetőségét is problematikussá teszi. A szerző a jobb érthetőség kedvéért a felszívódás helyett a szellemi elmerülés, az elmerülés helyett pedig a fizikai/virtuális elmerülés kifejezések használatát veti fel. Ezek húen tükrözik az eredeti gondolatot, azonban az élmény egyénbe való felszívódása, valamint az egyén élményben való elmerülése helyett leegyszerúsítik a két végletet.

\section{Az élmény négy dimenziója}

3. ábra

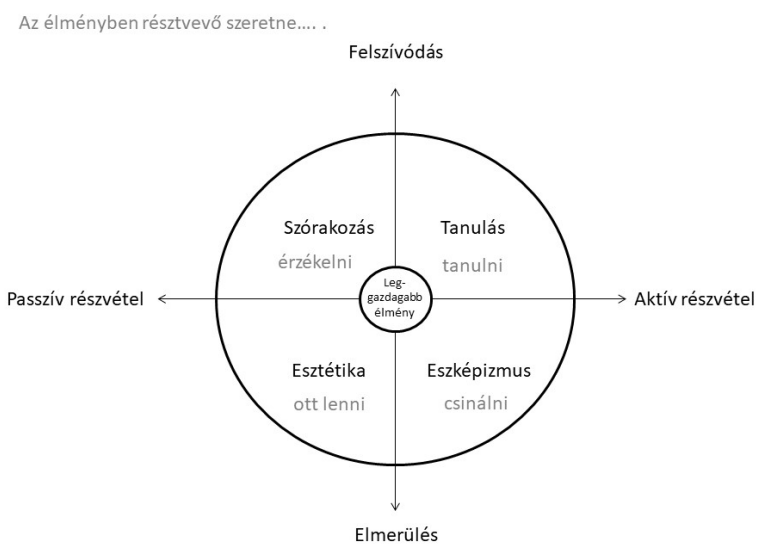

Forrás: saját szerkesztés PINE és GILMORE (1998) alapján

A négy dimenzió középpontjában a szerzők szerint a leggazdagabb élményt jelentó úgynevezett sweet spot található.

\subsection{SZÓRAKOZÁSI ÉLMÉNY}

A szórakozás dimenzióját a passzív felszívódás jellemzi, amikor az élmény az érzékszerveken keresztül áramlik a látogatóba oly módon, hogy ő csak egy kívülálló szemlélő, nem befolyásolja a dolgok kimenetelét. Szórakozási élmény például az edelényi L'Huillier-Coburg-kastélyban megnézni a 3D-s filmvetítést a kastély történetéról és Magyarország legnagyobb összefüggó rokokó falképéről.
A 3. ábrán a dimenziókban egy szemléletes gondolatmenet alapján látható, hogy az egyes esetekben mit szeretne a résztvevő: érzékelni, tanulni, ott lenni, csinálni. A szórakozási élmény során az egyén PINE és GILMORE (1999) szerint érzékelni szeretne (az angol „sense” szóhoz illeszkedve).

\subsection{TANULÁSI ÉLMÉNY - SZÓRAKOZVA TANULÁS ÉLMÉNYE}

A tanulás dimenziójában minden esetben aktív résztvevőre van szükség annak érdekében, hogy valóságos élmény legyen a végeredmény. A tanulás során a "tanuló" szellemileg kerül bevonásra, és tanulni szeretne, az élmény pedig a sikerből, az új ismeretek birtoklásából adódik.

Habár az oktatás komoly dolog, ez nem jelenti azt, hogy nem lehet szórakoztató, ezt bizonyítja a korábban bemutatott szórakozva tanulás gyakorlata. Felvetődik azonban a kérdés, hogy ez hol helyezkedik el a 4E modellben. RADDER és HAN (2015) szerint ez egyértelmúen a szórakozási és a tanulási dimenziók összemosódása, egy dimenzióként való értelmezése. Az egyes dimenziók vizsgálata során azonban ez az álláspont nem bizonyul teljes egészében megalapozottnak. Az oktatás során a "tanuló" szellemi és fizikai elmerülése is megvalósulhat. A felvetés relevanciáját ugyancsak alátámasztja, hogy a szórakozva tanulás WHITE és társai (2004) szerint háromféle lehet:

- interaktív és részvételi alapú (mint például az Élő történelem! címú interaktív színházi program a szentendrei Skanzenben);

- nem interaktív (például egy film megtekintése Pompeii romvárosának régészeti feltárásáról és annak virtuális rekonstrukciójáról);

- a kettő kombinációja (például egy XIX. századi történet olvasása az amszterdami csatornák egyikébe esett lóról, majd a látogatók számára megépített darumakett segítségével egy ló kiemelése a vízból, Amsterdam Múzeum).

Ez alapján különbséget lehet tenni a szórakozva tanulás élményének egyes típusai között, ahogyan az a 4. ábrán látható.

Az 1-es kategória, vagyis az interaktív, részvételi alapú edutainment típusa fizikai bevonódást (immerziót) jelentő tanulási élménnyel írható le, amely az eszképizmus és a tanulás metszetére helyezhetó.

A 2-es kategória, vagyis a nem interaktív edutainment jellegú események a szórakozás és a tanulás metszetére helyezhetőek. Ezek az élmények a szellemi bevonódásra építenek.

A WHITE és társai (2004) által kombinált, 3-as típusú edutainmentnek nevezett kategória egy 
komplex program esetén élhetó át, ahol mind az interaktív, mind a nem interaktív elemek felfedezhetőek.

4. ábra

Edutainment (szórakozva tanulás) két típusa PINE és GILMORE 4E modelljében ${ }^{3}$

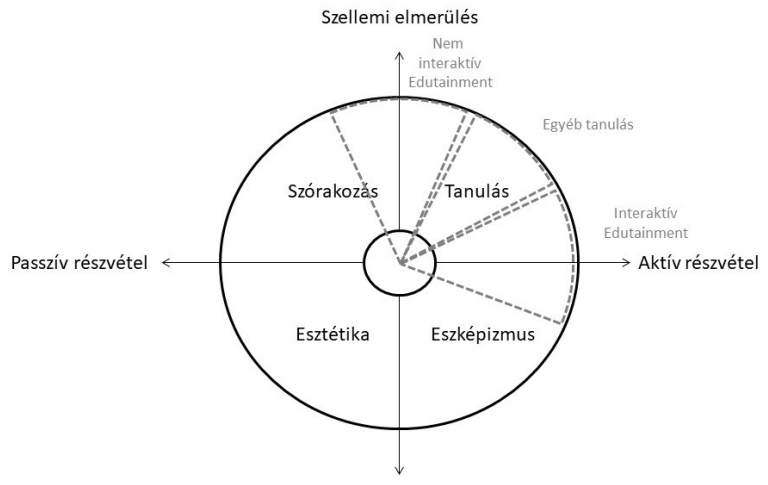

Fizikai/virtuális elmerülés

Forrás: saját szerkesztés PINE és GILMORE (1998) alapján

Az ábrán jelölt "egyéb tanulás" kategória a nem edutainment, vagyis nem szórakoztató jellegú tanulási élményt szimbolizálja, ez teljes egészében a tanulás dimenziójában található.

A fizikai bevonódás (kipróbálás, learning by doing), tehát a fentiekben interaktív edutainmentnek nevezett kategória, az esetek többségében jobban szolgálja a megértést, mint a szellemi bevonódás.

\subsection{ESZKÉPISTA ÉLMÉNY}

Az eszképizmus sokkal „immerzívebb", mint a szórakozás vagy a tanulás, hiszen az egyén teljesen elmerül az élményben, annak aktív részese lesz. Jó példa erre a skót Blair-kastélyban a korabeli ruhák felöltésének lehetôsége vagy a bécsi Zene Háza múzeumban a Bécsi Filharmonikusok vezénylése virtuális formában, ahol a zenészek humorosan reagálnak is a látogatók teljesítményére.

Az eszképizmus kifejezés az angol escape szóból ered, amelynek jelentése kilépés, menekülés, szökés. PINE és GILMORE ezzel a való világból, a mindennapi életből az élmény által történó kilépésre utal. Az egyén azzal szemben, hogy otthon ülne, és nézné, ahogyan más tevékenykedik, ő maga válik az események részesévé, szereplöjévé. $A z$ eszképista élmény tipikus helyszíne PINE és GILMORE (1998) szerint a tematikus parkok, chat szobák, virtuális headsetek, kaszinók vagy épp a környékbeli erdó egy paintballozás során.

\footnotetext{
${ }^{3}$ A modellben és a 3 típus megnevezésében a szerző tudatosan a szórakozva tanulás angol nyelvű megfelelőjét (edutainment) alkalmazta annak érdekében, hogy rövid és szemléletes megnevezések szülessenek.
}

Korábban az jelentette a nagy áttörést, hogy egy olvasmányélményt az emberek a filmvásznon láttak, egyre nagyobb felületen, egyre jobb hangeffektekkel, egyre kényelmesebb fotelekben, stb. Manapság a 4D-s mozik vonzzák a közönséget, ahol a néző részese lehet a filmnek, beléphet egy másik világba, a széke azzal együtt mozog, a hangok és más effektek körbeveszik (vízcseppek, hideg/meleg fuvallat, stb.). Az egyre komolyabb élményt nyújtó mozikat a komplex virtuális élmények és a tematikus parkokban átélhetó, úgynevezett motion simulator ride élmények követték, amelyek általában népszerú kalandfilmeken vagy sci-fiken alapultak (például Star Wars, Aladdin repülőszőnyege, Vissza a jövőbe). Habár a saját világából való elmenekülés már önmagában fontos része az élménynek, a kifejezéssel ellentétben a látogató nem csupán kilép valahonnan, hanem meg is érkezik egy másik világba, amelyben élvezetes élmények várják. PINE és GILMORE e kategória részének tekinti az extrém sportot úzóket is, akik egy nyaralás során már nem csak fekszenek a napon, hanem windsurföznek, hegyet másznak, vadvízi eveznek, stb. Kiemelten fontos eszképista helyszínnek tartják a kaszinókat, ahol a játékosok megszabadulnak a gátlásaiktól, és izgalommal vegyes borzongással kockáztatják a pénzüket egy másik - a mindennapitól távol esó - világban.

PINE és GILMORE (1998) gondolatsora szerint az eszképizmus élménye keretében az egyén csinálni szeretne valamit, fizikailag (virtuálisan) akar aktív részese lenni egy eseménynek.

\subsection{ESZTÉTIKAI ÉLMÉNY}

PINE és GILMORE élménymodelljének negyedik dimenziója az esztétika, ahol az egyén passzív résztvevóje az élménynek, de az eszképizmushoz hasonlóan fizikailag (virtuálisan) is részévé válik. Bár passzív szemlélóként, az eszképizmussal szemben, érintetlenül hagyja a környezetét, saját magát nem, hiszen az ő szellemét, lelkét megragadja az esztétikai élmény, így a szellemi bevonódás, a felszívódás is érintett lehet bizonyos esetekben. Mivel azonban nincs hatással a környezetére, nem befolyásolja az események kimenetelét. Esztétikai élmény lehet a Szarvasi Arborétumban sétálni vagy a Szépmúvészeti Múzeum felújított Román Csarnokát megcsodálni.

Az esztétika dimenzióban az egyén egyszerúen csak szeretne ott lenni az adott környezetben, amelynek harmonikus jellege eredményezi az élményt.

Egy attrakció látogatója választhat csupán egyfajta élményt a négyből, de kombinálhat akár többet is, egymást követóen vagy egymással párhuzamo- 
Lektorált tanulmányok

san. A szolgáltató a lehetséges élmények környezetét tudja kialakítani (WALLS et al. 2011), ezzel ösztönözve a látogatót arra, hogy a számára releváns, érdekes elemeket kiválogatva alkossa meg a saját élményét. Az, hogy mely elemek ragadják meg, az előzetes tapasztalatain, motivációin, stb. múlik (PACKER-BALLANTYNE 2016), így alakul ki az élmény lehetóségéból az azonnali szubjektív élmény. Vagyis az, hogy a négy dimenzió által leírt lehetőségek tárházából mit ragad ki, az egyénen múlik. Amennyiben lehetősége van az emberi mozgás által termelt energiát mérni egy természettudományi múzeumban, onnantól már csak a látogatón múlik, hogy csak néz másokat, vagy felül egy biciklire, és a tekerés által múködésbe hoz egy gépet.

PINE és GILMORE modelljét először OH és társai (2007) tesztelték a turizmus területén, azonban korábbi érvényes mérési skálát nem találtak a modellhez kapcsolódóan. A 4E modellt, mint mérési módszert később számos kutatás során alkalmazták a turizmus különböző területén $(\mathrm{OH}$ et al. 2007, JUROWSKI 2009, MEHMETOGLU-ENGEN 2011, WILLARD et al. 2012, RADDER-HAN 2015, SUNTIKUL-JACHNA 2016, ÁSVÁNYI et al. 2017, ÁSVÁNYI et al. 2018).

\subsection{A 4E MODELL ESZKÉPIZMUS DIMENZIÓJÁNAK ELEMZÉSE}

A modell értelmezése az egyes szakterületeken belül különböző lehet. Az eszképizmusnak három fó jelentése határozható meg az elemzett szakirodalom alapján:

- aktív fizikai elmerülés a 4E modell eredeti kategorizálásának megfelelően;

- elmenekülés a virtuális világba (PINEGILMORE 1999);

- elmenekülés a mindennapi problémák elól (PINE-GILMORE 1998).

Az eszképizmus dimenzióját PINE és GILMORE (1999) sokkal korlátozottabban értelmezi annál, mint amilyen jelentôsége ennek a szegmensnek lehet egy turisztikai élmény kapcsán. Ez a szegmens (aktív fizikai elmerülés) a múzeumi látogatói élmény kapcsán a legfontosabb módszertani elveket magába foglaló terület (például az interaktivitás, a bevonódás, a több érzékszervre hatás, az interaktív edutainment).

Az 1999-ben megjelent könyv alapján úgy túnik, hogy PINE és GILMORE a virtuális élményeknek szánja a legnagyobb szerepet, amely a virtuális világba, egy ",harmadik helyre" való elszökést jelentette. Ezzel szemben a szerzők egy 2013-as munkájukban hangsúlyozzák, hogy „félreértelmezés azt fel- tételezni, hogy minden élmény a hiteltelenség/nem autentikus jelleg vagy a virtuális felé tart" (PINEGILMORE 2013:32). Ennek egy kicsit ellent is mondana az a szemléletes gondolatsor, amely szerint az eszképizmus élményét átélő csinálni, tenni akar, így viszont csak virtuálisan csinálhatna valamit, nem a való világban. A szakirodalom áttekintése ugyanakkor számos olyan kutatásra irányította a figyelmet, ahol a szerzók a virtuális világba való elszökést értik az eszképizmus élménye alatt (online játékok, közösségi média, virtuális valóság, stb.).

Az escapism elnevezés rendkívül beszédes, így kézenfekvő, hogy ebból indul ki a legtöbb szerzó, aki a modell alkalmazásával foglalkozik. Ahogyan PINE és GILMORE Harvard Business Review-ban (1998) megjelent cikkében is ez az értelmezés jelenik meg, úgy a késóbbi, erre épító kutatások során is a hétköznapi problémáktól való elmenekülés jelentéstartalmat használják a szerzók. A megnevezésból adódó egyértelmúnek túnő következtetés azonban a turizmus területén félrevezetô lehet, hiszen az utazás egy alapvetó motivációját emeli be az élménymodell egy szegmensébe. Egy olyan motivációt, amely a tevékenység egészét jellemzi, legyen annak eredménye esztétikai, szórakozási, tanulási vagy eszképista élmény.

\subsection{ESZKÉPIZMUS, MINT ÁLTALÁNOS TURISZTIKAI MOTIVÁCIÓ}

Az eszképizmus a kilép, elszökik, elmenekül szó angol fordításából adódóan könnyen azonosítható a turizmus és az utazás egyik legáltalánosabb, legtöbbet említett alapvető motivációjával, ahogyan azt OH és társai (2007) is alátámasztják PRENTICE és társai (2004) tömegturizmus paradigmájára hivatkozva. STAMBOULIS és SKAYANNIS (2003) szerint a turizmust elsősorban egy másik életforma megismerése, meglátogatása, megtekintése, élvezete, megélése során tapasztalt élménnyel lehet jellemezni. COHEN (1979) az utazás egyik alapvető indítékaként határozza meg a jelentóségteljes élettôl és/vagy a mindennapi élettől eltérő helyen található „énközpont” után való kutatást. GROSS (1961) és pozitív funkcionalista társai a turisták elszökését egy kikapcsolódást jelentő szabadidős tevékenységnek tekintik, ami elengedhetetlen az élet és a társadalom egészséges múködéséhez. Ezzel szemben BOORSTIN (1964) és MacCANNELL (1973) amellett érvelnek, hogy az emberek hamis, egymástól elidegenedett életet élnek, és alkalmankénti utazásaik keretében ebból a boldogtalan világból menekülnek át más kultúrákba és országokba egy autentikusabb, kielégítőbb életet keresve. A turisták talán a mindennapjaikat vezérlő normák és értékek kötelékétól akarnak megszabadulni, 
amikor kilépnek a szokásos környezetükból, vagy esetleg külső perspektívából szeretnék látni saját életüket és társadalmukat.

\subsection{ESZKÉPIZMUS FOGALMA A KÜLÖNBÖZŐ MÉRÉSI SKÁLÁKBAN}

Az eszképizmus fogalmát vagy az annak megfeleltethetô egyéb fogalmakat (például playfulness, evasion) számos mérési skálában használják, amelyekben a változók meghatározása eltéró $(\mathrm{OH}$ et al. 2007, MEHMETOGLU-ENGEN 2011, KANGGRETZEL 2012, SHIH 2015, RADDER-HAN 2015, SEMRAD-RIVERA 2016, SUNTIKUL-JACHNA 2016, SIPE-TESTA 2018). Az eszképizmus fogalmát az említett skálákban jellemzően az alábbi változók alkotják:

- mindennapi rutinból való elmenekülés,

- egy másik valóságban való elmélyülés,

- egy másik világba történő átlépés,

- mindentől elszökni,

- teljesen megfeledkezni az időról,

- minden másról megfeledkezni,

- másik térben és időben zajló élet érzése.

A fenti változók megfogalmazásának sokszínúsége azt támasztja alá, hogy az eszképizmus dimenzióját - néhány kivételtól eltekintve - nem az eredetileg azt meghatározó aktív fizikai/virtuális részvételt jelentő változókkal írják le az egyes szerzők.

\section{A 4E modell továbbfejlesztett koncepciója}

Jelen munka során a szerző PINE és GILMORE 4E modelljének továbbfejlesztését javasolja múzeumi kontextusban, oly módon, hogy az eszképizmust, mint élménydimenziót, a négy dimenziót átfogó tényezőnek tekinti, a negyedik dimenziót pedig egy új, „Aktív bevonódás" megnevezéssel látja el. Ahogyan azt korábban említette, a modellben alkalmazott felszívódás és elmerülés kifejezéseket ugyancsak módosításra javasolja, a szellemi és a fizikai/virtuális elmerülés elnevezéseket használva. A fenti koncepcionális keretet az 5. ábra szemlélteti.

A szerző szerint az aktív bevonódás lehet mind fizikai, mind virtuális, azonban kiemelten fontosnak tartja a fizikai bevonódás lehetőségeit, fóként a múzeumi kontextusban, eltéróen az eredeti modell virtuális fókuszú szemléletétôl. A szerző feltételezése szerint ezen dimenziót erôsítik a fentiekben elemzett interpretációt segítő módszerek, azok aktivitást igénylô, fizikai bevonásra épító jellege okán.
PINE és GILMORE 4E modelljének 5. ábra továbbfejlesztett koncepciója múzeumi közegben

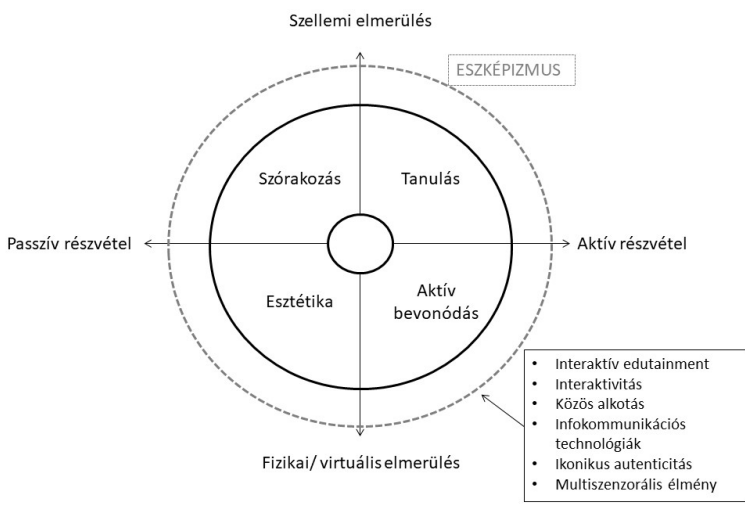

Forrás: saját szerkesztés

A modellben az eszképizmus, mint a hétköznapi gondoktól való eltávolodás, ami az egyik leggyakrabban említett turisztikai motiváció $(\mathrm{OH}$ et al. 2007), átfogó, általános tényezőként jelenik meg, nem korlátozódik egyetlen dimenzióra, hanem hatást gyakorol minden élménydimenzióra, és bármely élmény kapcsán megtalálható a látogatóban. Ahogyan OH és társai (2007:122) is megjegyezték ",mindegy, hogy hova megy a turista, mit csinál", a hétköznapi gondoktól való eltávolodás mindenképp jelen van a motivációjában.

\section{Jövőbeli kutatási irányok}

Jelen cikk elkészültének időpontjáig a szerzőnek nincs tudomása PACKER és BALLANTYNE (2016) tízoldalú élménymodelljének érvényességét vizsgáló empirikus kutatásról, amelyet egy lehetséges jövőbeli kutatási irányként határoz meg. További kutatási téma, hogy milyen tényezőktôl függ, hogy PINE és GILMORE 4E modelljében a sweet spot mely dimenzióban helyezkedik el az egyének számára. Az is megvizsgálandó, hogy van-e valamilyen hierarchikus sorrend az egyes dimenziók között, esetleg beszélhetünk-e az élmények Maslow-piramisáról.

\section{8. Összefoglalás}

Az 1970-es évektól napjainkig olyan folyamatok mentek végbe, amelyek a múzeumi szakmában elterjedt új szemléletmódhoz, az új muzeológiához vezettek. A célközönség bővítése, a szórakozási, szabadidős funkció megjelenése, valamint a fenntartási gondok kiküszöbölése érdekében a látogatószám növelésére való törekvés arra sar- 
kallja a szakembereket, hogy próbáljanak minél inkább megfelelni a látogatói igényeknek. A szerző a PINE és GILMORE (1998) által alkotott látogatói élmény mérésére szolgáló modellt helyezi a cikk középpontjába. A 4E modellben elhelyezi a szórakozva tanulás gyakorlatát, amely annak típusától függóen akár három dimenzióban is megjelenhet. Vizsgálja továbbá az eszképizmus dimenziójának három különböző jelentéstartalmát (aktív bevonódás, elmenekülés a virtuális világba, elmenekülés a hétköznapi gondoktól), és megállapítja, hogy múzeumi kontextusban az aktív bevonódás értelmezési köre a legjelentősebb. Az aktív bevonódást a különböző interpretációs módszerek, mint például interaktív edutainment, több érzékszervre ható élmények, közös alkotás, segítik elő, amelyek erôteljesen befolyásolják a látogatói élményt és az elégedettséget. A szerzó továbbfejleszti a $4 \mathrm{E}$ modellt oly módon, hogy az általános turisztikai motivációként értelmezett eszképizmust (elmenekülés a hétköznapi gondoktól) mind a négy dimenziót befolyásoló tényezóként emeli ki, ahol negyedik dimenzióként az aktív bevonódást (fizikai/virtuális) nevezi meg. A továbbfejlesztett modellt a szerző a jövőben múzeumi kontextusban kívánja tesztelni kvalitatív és kvantitatív kutatás keretében.

\section{Felhasznált irodalom}

ADDIS, M. (2005): New technologies and cultural consumption - Edutainment is born! European Journal of Marketing. 39(7-8). pp. 729-736.

ÁSVÁNYI K. - JÁSZBERÉNYI M. - BODNÁR D. (2017): Egy budapesti múzeum az élményvágyó kulturális turista szemében. In: Bányai E. - Lányi B. - Törőcsik M. (szerk.): Tükröződés, társtudományok, trendek, fogyasztás. EMOK XXIII. országos konferencia tanulmánykötete. Pécsi Tudományegyetem, Közgazdaságtudományi Kar, Pécs. pp. 5-13.

ÁSVÁNYI K. - MITEV A. - JÁSZBERÉNYI M. (2018): Családbarát fesztivál, avagy a családok fesztiválélménye. In: Józsa L. - Korcsmáros E. Seres Huszárik E. (szerk.): A hatékony marketing. EMOK 2018 Nemzetközi Tudományos Konferencia konferenciakötete. Selye János Egyetem, Komarno, Szlovákia. pp. 289-300.

BARON, S. - HARRIS, K. - HARRIS, R. (2001): Retail theater: The "Intended Effect" of the performance. Journal of Service Research. 4(2). pp. 102-117.

BEATON, A. A. - FUNK, D. C. - ALEXANDRIS, K. (2009): Operationalizing a theory of participation in physically active leisure. Journal of Leisure Research. 41(2). pp. 177-203.
BLOOM, M. V. - HANYCH, D. A. (2002): Skeptics and true believers hash it out. Community College Week. 4(14).

BODNÂR D. - JÁSZBERÉNYI M. - ÁSVÁNYI K. (2017): Az új muzeológia megjelenése a budapesti múzeumokban. Turizmus Bulletin. 17(1-2). pp. 45-55.

BOORSTIN, D. (1964): The Image: A Guide to PseudoEvents in America. Harper, New York.

BRADBURNE, J. M. (2002): Museums and their languages. Is interactivity different for fine art as opposed to design? Interactive Learning in Museums of Art and Design. Konferenciakötet. London. http://media.vam. ac.uk/media/documents/legacy_documents/ file_upload/5758_file.pdf

BRUNER, J. S. - JOLLY, A. - SYLVA, K. (1976): Play: its role in development and evolution. Basic Books, New York.

CHATTERJEE, H. J. - NOBLE, G. (2013): Museums, health and wellbeing. Ashgate Publishing Ltd., Farnham.

CIOLFI, L. - BANNON, L. J. (2002): Designing interactive museum exhibits: enhancing visitor curiosity through augmented artefacts. Proceedings of the Eleventh European Conference on Cognitive Ergonomics. Catania, Italy. pp. 1-7.

COHEN, E. (1979): A phenomenology of tourism experiences. Sociology. 13(2). pp. 179-201.

COUNTS, C. M. (2009): Spectacular design in museum exhibitions. Curator: The Museum Journal. 52(3). pp. 273-288.

CSÍKSZENTMIHÂLYI， M. (1990): Flow: The psychology of optimal experience - steps toward enhancing the quality of life. Harper Collins Publisher, New York.

DEWEY, J. (1938/Reprinted 1963): Experience and education. Collier-Macmillan, London.

DIRSEHAN, T. (2012): Analyzing museum visitor experiences and post experience dimensions using SEM. Bogazici Journal: Review of Social, Economic \& Administrative Studies. 26(1). pp. 103-125.

DOLCOS, F. - CABEZA, R. (2002): Event-related potentials of emotional memory: Encoding pleasant, unpleasant, and neutral pictures, cognitive. Affective $\mathcal{E}$ Behavioral Neuroscience. 2(3). pp. 252-263.

EARDLEY, A. F. - MINEIRO, C. - NEVES, J. RIDE, P. (2016): Redefining access: Embracing multimodality, memorability and shared experience in Museums. Curator: The Museum Journal. 59(3). pp. 263-286.

FALK, J. H. - SCOTT, C. - DIERKING, L. RENNIE, L. - JONES, M. C. (2004): Interactives and visitor learning. Curator: The Museum Journal. 47(2). pp. 171-198. 
FERREIRA, H. - TEIXEIRA, A. A. C. (2013): „Welcome to the experience economy": assessing the influence of customer experience literature through bibliometric analysis. FEP Working Papers 481. Universidade do Porto, Faculdade de Economia do Porto.

FORGAS-COLL, S. - PALAU-SAUMELL, R. MATUTE, J. - TÁRREGA, S. (2017): How do service quality, experiences and enduring involvement influence tourists' behavior? An empirical study in the Picasso and Miró museums in Barcelona. International Journal of Tourism Research. 19(2). pp. 246-256.

GOODLAD, S. - McIVOR, S. (1998): Museum volunteers: Good practice in the management of volunteers. Routledge, London.

GOULDING, C. (2000): The museum environment and the visitor experience. European Journal of Marketing. 34(3-4). pp. 261-278.

GROSS, E. (1961): A functional approach to leisure analysis. Social Problems. 9(1). pp. 2-8.

HARLEY, D. - McBRIDE, M. - CHU, J. H. KWAN, J. - NOLAN, J. - MAZALEK, A. (2016): Sensing context: Reflexive design principles for intersensory museum interactions. MW2016: Museums and the Web. Los Angeles, USA.

HARRISON, J. D. (1993): Ideas of museums in the 1990s. Museum Management and Curatorship. 13(2). pp. 160-176.

HARRISON, P. - SHAW, R. (2004): Consumer satisfaction and post-purchase intentions: an exploratory study of museum visitors. International journal of arts management. 6(2). pp. 23-32.

HARVEY, M. L. - LOOMIS, R. J. - BELL, P. A. MARINO, M. (1998): The influence of museum exhibit design on immersion and psychological flow. Environment and Behavior. 30(5). pp. 601-627.

HENNES, T. (2010): Exhibitions: From a perspective of encounter. Curator: The Museum Journal. 53(1). pp. 21-33.

HEWISON, R. (1987): The heritage industry - Britain in a climate of decline. Methuen, London.

HJALAGER, A. M. (2010): A review of innovation research in tourism. Tourism Management. 31(1). pp. 1-12.

HOOPER-GREENHILL, E. (1999): Museums: ideal learning environment. Museums and their visitors. Routledge, London.

HOOPER-GREENHILL， E. (2007): Museums and education: Purpose, pedagogy, performance. Routledge, London.

HOU, J. S. - LIN, C. H. - MORAIS, D. B. (2005): Antecedents of attachment to a cultural tourism destination: The case of Hakka and NonHakka Taiwanese visitors to Pei-Pu, Taiwan. Journal of Travel Research. 44(2). pp. 221-233.
HOUSTON, M. J. - ROTHSCHILD, M. L. (1978): Conceptual and methodological perspectives in involvement. In: Jain, S. C. (ed): Research Frontiers in Marketing: Dialogues and Directions. American Marketing Association: Chicago. pp. 184-187.

HUANG, C. Y. - CHOU, C. J. - LIN, P. C. (2010): Involvement theory in constructing bloggers' intention to purchase travel products. Tourism Management. 31(4). pp. 513-526.

HUANG, Y. - SCOTT, N. - DING, P. - CHENG, D. (2012): Impression of Liusanjie: Effect of mood on experience and satisfaction. International Journal of Tourism Research. 14(1). pp. 91-102.

HUDSON, K. (1977): Museums for the 1980s: A survey of world trends. UNESCO/Macmillan, Paris and London.

HUDSON, K. (1998): The museum refuses to stand still. Museum International. 50(1). pp. 43-50.

HUME, M. (2015): To technovate or not to technovate? Examining the inter-relationship of consumer technology, museum service quality, museum value, and repurchase intent. Journal of Nonprofit \& Public Sector Marketing. 27(2). pp. 155-182.

JEGERS, K. - WIBERG, C. (2003): FunTain: Design implications for edutainment games. ED-MEDIA '03: World Conference on Educational Multimedia, Hypermedia and Telecommunications (Ed-Media). Chesapeake, VA, AACE. Konferenciakötet.

JUROWSKI, C. (2009): An examination of the four realms of tourism experience theory. In: International CHRIE Conference. University of Massachusetts. Available via: https://scholarworks.umass.edu/cgi/viewcontent.cgi?referer=https://www.google.hu/\&httpsredir=1\&article $=1054 \&$ context $=$ refereed

KANG, M. -GRETZEL, U. (2012): Effects of podcast tours on tourist experiences in a national park. Tourism Management. 33(2). pp. 440-455.

KIM, H. - WOO, E. - UYSALl, M. (2015): Tourism experience and quality of life among elderly tourists. Tourism Management. 46(Feb.). pp. 465-476.

KOTLER, N. - KOTLER, P. (2000): Can museums be all things to all people? Missions, goals, and marketing's role. Museum Management and Curatorship. 18(3). pp. 271-287.

LAI, M. K. (2015): Universal scent blackbox: engaging visitors communication through creating olfactory experience at art museum. Proceedings of the 33rd Annual International Conference on the Design of Communication. Limerick, Ireland. ACM. pp. 1-6.

LEE, T. H. - CHANG, Y. S. (2012): The influence of experiential marketing and activity involvement 
on the loyalty intentions of wine tourists in Taiwan. Leisure Studies. 31(1). pp. 103-121.

LEIGH, T. - PETERS, C. - SHELTON, J. (2006): The consumer quest for authenticity: The multiplicity of meanings within the MG subculture of consumption. Journal of the Academy of Marketing Science. 34(4). pp. 481-493.

LU, L. - CHIU, C. G. - LIU, Y. (2015): Authenticity, involvement, and image: Evaluating tourist experiences at historic districts. Tourism Management. 50(Oct.). pp. 85-96.

MacCANNELL, D. (1973): Staged authenticity: Arrangements of social space in tourist settings. American Journal of Sociology. 79(3). pp. 589-603.

MASBERG, B. A. - SILVERMAN, L. H. (1996): Visitor experiences at heritage sites: A phenomenological approach. Journal of Travel Research. 34(4). pp. 20-25.

McINTOSH, A. J. - SIGGS, A. (2005): An exploration of the experiential nature of boutique accommodation. Journal of Travel Research. 44(1). pp. 74-81.

McINTYRE, N. (1989): The personal meaning of participation: Enduring involvement. Journal of Leisure Research. 21(2). pp. 167-179.

MEHMETOGLU, M. - ENGEN, M. (2011): Pine and Gilmore's concept of experience economy and its dimensions: An empirical examination in tourism. Journal of Quality Assurance in Hospitality \& Tourism. 12(4). pp. 237-255.

MICHALKÓ G. - RÁTZ T. (2005): A kulturális turizmus élmény-gazdaságtani szempontjai. In: Enyedi Gy. - Keresztély K. (szerk.): A magyar városok kulturális gazdasága. MTA Társadalomkutató Központ, Budapest. pp. 123141.

MOORE, K. (1997): Museums and popular culture. Cassell, London.

OH, H. - FIORE, A. M. - JEOUNG, M. (2007): Measuring experience economy concepts: Tourism applications. Journal of Travel Research. 46(2). pp. 119-132.

PACKER, J. - BALLANTYNE, R. (2002): Motivational factors and the visitor experience: A comparison of three sites. Curator: The Museum Journal. 45(3). pp. 183-198.

PACKER, J. - BALLANTYNE, R. (2016): Conceptualizing the visitor experience: A review of literature and development of a multifaceted model. Visitor Studies. 19(2). pp. 128-143.

PEIRCE, C. S. (1998): Collected papers of Charles Saunders Peirce. Thoemmes, Bristol.

PIAGET, J. (1995): Commentary on Vygotsky's criticisms of language and thought of the child and judgment and reasoning in the child. New Ideas in Psychology. 13(3). pp. 325-340.

PINE, B. J. II. - GILMORE, J. H. (1998): Welcome to the experience economy. Harvard Business Review. 76(4). pp. 97-105.

PINE, B. J. II. - GILMORE, J. H. (1999): The experience economy: Work is Theatre \& Every Business a Stage. Harvard Business Press, Boston.

PINE, B. J. II. - GILMORE, J. H. (2013): The experience economy: past, present and future. In: Sundbo, J. - Sørensen, F. (eds): Handbook on the Experience Economy. Edward Elgar Publishing. pp. 21-44.

PREBENSEN, N. K. - KIM, H. - UYSAL, M. (2015) Cocreation as moderator between the experience value and satisfaction relationship. Journal of Travel Research. 55(7). pp. 934-945.

PRENTICE, R. (2001): Experiential cultural tourism: Museums \& the marketing of the new romanticism of evoked authenticity. Museum Management and Curatorship. 19(1). pp. 5-26.

PRENTICE, R. C. (2004): Tourism motivation and typologies. In: Lew, A. - Hall, M. - Williams, A. M. (eds): A companion to tourism. Pergamon, Oxford. pp. 261-279.

RADDER, L. - HAN, X. (2015): An examination of the museum experience based on Pine and Gilmore's experience economy realms. Journal of Applied Business Research. 31(2). pp. 455-470.

ROUNDS, J. (1999): Meaning making: A new paradigm for museum exhibits? Exhibitionist. 18(2). pp. 5-8.

SALOMON, G. (1983): The differential investment of mental effort in learning from different sources. Educational Psychologist. 18(1). pp. 4250.

SANDELL, R. (2007): Museums, prejudice and the reframing of difference. Routledge, Oxon.

SCHMITT, B. H. (1999): Experiential marketing: How to get customers to sense, feel, think, act, relate to your company and brands. The Free Press, New York.

SEMRAD, K. J. - RIVERA, M. (2016): Advancing the 5E's in festival experience for the Gen $Y$ framework in the context of eWOM. Journal of Destination Marketing \& Management. 7. pp. 58-67.

SHIH, T. Y. (2015): Attribute design and marketing strategy of branding experience museums. International Journal of Electronic Business Management. 13(Dec.). pp. 85-96.

SILVERMAN, L. (1995): Visitor meaning-making in museums for a new age. Curator: The Museum Journal. 38(3). pp. 161-170. 
SIMPSON, M. (1996): Making representations: Museums in the post-colonial era. Routledge, London.

SIPE, L. J. - TESTA, M. R. (2018): From satisfied to memorable: An empirical study of service and experience dimensions on guest outcomes in the hospitality industry. Journal of Hospitality Marketing \& Management. 27(2). pp. 178-195.

STAMBOULIS, Y. - SKAYANNIS, P. (2003): Innovation strategies and technology for experience-based tourism. Tourism Management. 24(1). pp. 35-43.

SUNTIKUL, W. - JACHNA, T. (2016): Profiling the heritage experience in Macao's historic center. International Journal of Tourism Research. 18(4). pp. 308-318.

SWARBROOKE, J. (2000): Museums: theme parks of the third Millennium? In: Robinson, M. (ed): Tourism and heritage relationships: Global, national and local perspectives (Reflections on international tourism). Business Education Publisher, Sunderland. pp. 417-431.

THYNE, M. (2001): The importance of values research for nonprofit organisations: The motivation-based values of museum visitors. International Journal of Nonprofit and Voluntary Sector Marketing. 6(2). pp. 116-130.

THYNEA, M. - HEDE, A. M. (2016): Approaches to managing co-production for the co-creation of value in a museum setting: when authenticity matters. Journal of Marketing Management. 32(15-16). pp. 1478-1493.

TOMIUC, A. (2014): Navigating culture. Enhancing visitor museum experience through mobile technologies. From Smartphone to Google Glass. Journal of Media Research. 7(3). pp. 33-47.

TRILLING, L. (1978): Sincerity and authenticity. Oxford University Press, London.
VARGO, S. L. - LUSCH, R. F. (2004): Evolving to a new dominant logic for marketing. Journal of Marketing. 68(1). pp. 1-17.

VI, C. T. - ABLART, D. - GATTI, E. - VELASCO, C. - OBRIST, M. (2017): Not just seeing, but also feeling art: Mid-air haptic experiences integrated in a multisensory art exhibition. International Journal of Human-Computer Studies. 108(Dec.). pp. 1-14.

VYGOTSKY, L. S. (1978): Interaction between learning and development. In: Cole, M. - JohnSteiner, V. - Scribner, S. - Souberman, E. (eds): Mind and Society: The Development of Higher Psychological Processes. Harvard University Press, Cambridge. pp. 79-91.

WALLS, A. R. - OKUMUS, F. - WANG, Y. KWUN, D. J. W. (2011): An epistemological view of consumer experiences. International Journal of Hospitality Management. 30(1). pp. 10-21.

WANG, N. (1999): Rethinking authenticity in tourism experience. Annals of Tourism Research. 26(2). pp. 349-370.

WEAVER, S. (2007): Creating great visitor experiences: A guide for museums, parks, zoos, gardens, and libraries. Left Coast Press, Walnut Creek.

WHITE, R. - HAYWARD, M. - CHARTIER, P. (2004): Edutainment: The next big thing. Presented at IAAPA 2004 Orlando Convention. Orlando, USA, Available via: https://www. whitehutchinson.com/news/downloads/ IAAPAEdutainmentSeminar.pdf.

WILLARD, P. - FROST, W. - LADE, C. (2012): Battlefield tourism and the tourism experience: the case of Culloden. In: Cauthe 2012: The new golden age of tourism and hospitality. Book 2. Proceedings of the 22nd Annual Conference. La Trobe University, Melbourne. pp. 665-670. 